\title{
A Record-Breaking Trans-Atlantic African Dust Plume Associated with Atmospheric Circulation Extremes in June 2020
}

Bing Pu and Qinjian Jin

\begin{abstract}
High concentrations of dust can affect climate and human health, yet our understanding of extreme dust events is still limited. A record-breaking trans-Atlantic African dust plume occurred during 14-28 June 2020, greatly degrading air quality over large areas of the Caribbean Basin and the United States. Daily $\mathrm{PM}_{2.5}$ concentrations exceeded $50 \mu \mathrm{g} \mathrm{m}^{-3}$ in several Gulf States, while the air quality index reached unhealthy levels for sensitive groups in more than 11 states. The magnitude and duration of aerosol optical depth over the tropical North Atlantic Ocean were the greatest ever observed during summer over the past 18 years based on satellite retrievals. This extreme trans-Atlantic dust event is associated with both enhanced dust emissions over western North Africa and atmospheric circulation extremes that favor long-range dust transport. An exceptionally strong African easterly jet and associated wave activities export African dust across the Atlantic toward the Caribbean in the middle to lower troposphere, while a westward extension of the North Atlantic subtropical high and a greatly intensified Caribbean low-level jet further transport the descended, shallower dust plume from the Caribbean Basin into the United States. Over western North Africa, increased dust emissions are associated with strongly enhanced surface winds over dust source regions and reduced vegetation coverage in the western Sahel. While there are large uncertainties associated with assessing future trends in African dust emissions, model-projected atmospheric circulation changes in a warmer future generally favor increased long-range transport of African dust to the Caribbean Basin and the United States.
\end{abstract}

KEYWORDS: Africa; Dust or dust storms; Jets; Remote sensing; Atmospheric composition. 
$\mathrm{N}$ orth Africa is the world's largest dust source, contributing to $40 \%-70 \%$ of global dust emissions (Engelstaedter and Washington 2007; Huneeus et al. 2011). African dust can be transported to the Mediterranean and Europe, North and South America, and as far as East Asia (e.g., Engelstaedter et al. 2006; Prospero et al. 2014), affecting local and remote environment and climate, such as modulating West African monsoonal rainfall (e.g., Miller and Tegen 1998; Solmon et al. 2012; Strong et al. 2015), affecting the development of Atlantic cyclones (e.g., Karyampudi and Carlson 1988; Karyampudi and Pierce 2002; Dunion and Velden 2004; Evan et al. 2006; Braun 2010; Strong et al. 2018), decreasing vegetation cover and productivity over the Sahel (Evans et al. 2019), and providing nutrients for the Amazon rain forest (e.g., Bristow et al. 2010; Yu et al. 2015). High concentrations of dust also degrade visibility and cause respiratory diseases, affecting public transportation and health, respectively (e.g., Morman and Plumlee 2013; Schweitzer et al. 2018).

During boreal summer, the hot, dry, and dusty Saharan air layer (e.g., Carlson and Prospero 1972; Prospero and Carlson 1972, 1981; Braun 2010; Dunion 2011; Adams et al. 2012) extends vertically from 850 to about $500 \mathrm{hPa}$ (about 1.5-5.5 km) and often travels from West Africa across the tropical North Atlantic to the Caribbean Basin and the United States. The transport of African dust to the southeastern United States is strongest during June and July (e.g., Prospero et al. 2001; Engelstaedter et al. 2006), and it usually takes about a week for dust plumes to reach the Caribbean and 10-12 days to the continental United States (e.g., Ott et al. 1991; Haarig et al. 2017; Chen et al. 2018). The export and westward transport of African dust in boreal summer have been related to several factors, such as the propagation of the African easterly waves (AEWs) (Jones et al. 2003), the North Atlantic subtropical high (Doherty et al. 2008; Chen et al. 2018), the North Atlantic Oscillation (Moulin et al. 1997), the location of intertropical convergence zone (Doherty et al. 2014; Meng et al. 2017), Sahel precipitation (Moulin and Chiapello 2004), the atmospheric circulation over North African dust source regions (Schepanski et al. 2009, 2017; Rodríguez et al. 2015), and systems that affect African climate such as the Atlantic multidecadal oscillation (AMO) (Wang et al. 2012) and El Niño-Southern Oscillation (ENSO) (Prospero and Lamb 2003). However, the links between trans-Atlantic dust and Sahel precipitation and climate indices, such as AMO and ENSO, are weakened in recent years (Prospero and Mayol-Bracero 2013), which adds to the difficulty in understanding the variations in trans-Atlantic dust plumes in the current and future climate.

During 14-28 June 2020, a massive African dust plume traveled across the tropical North Atlantic and reached the United States, greatly degrading air quality over large areas in the Caribbean and the southeastern to central United States. The event received immense media coverage due to its severity and considerable impacts on large areas. It is not clear what caused the extreme trans-Atlantic dust event and whether similar events will occur more frequently in the future. Francis et al. (2020) examined this event and focused on the atmospheric drivers of the Saharan dust storm. They found that the intense dust storm was triggered by an anomalous subtropical high off the coast of West Africa. Yu et al. (2021, manuscript submitted to Atmos. Chem. Phys.) also studied this event using both observations and an Earth system model. In this paper, we first characterize this trans-Atlantic dust event and then examine the underlying mechanisms of the event. We address questions, such as, how extreme is this event? Is this event caused by extreme emissions or an enormously strong transport of African dust, or both? Are the circulation patterns associated with this event unique? We also briefly discuss whether more trans-Atlantic dust extremes might occur in the future. Our findings will advance current understanding of extreme trans-Atlantic African dust events and their environmental impacts and guide the future prediction of similar events.

\section{Data and methods}

Datasets used in this study are summarized in Table 1 with details given below. 
Satellite products. Aerosol optical depth (AOD) is the column-integrated light extinction by aerosol particles. Level 2 daily AOD at $550 \mathrm{~nm}$ retrieved from Moderate Resolution Imaging Spectroradiometer (MODIS; collection 6.1; Sayer et al. 2019) on board the Terra and Aqua satellites and from Visible Infrared Imaging Radiometer Suite (VIIRS; collection 1; Hsu et al. 2019) on board the Suomi National Polar-Orbiting Partnership (SNPP) satellite in June 2020 are used to examine the westward propagation of this African dust plume. It is found that MODIS and VIIRS AOD agree well with the Aerosol Robotic Network (AERONET; Holben et al. 1998, 2001) station observations (Hsu et al. 2019; Sayer et al. 2019). We regridded level 2 AOD from the three sensors to a $0.25^{\circ} \times 0.25^{\circ}$ grid and averaged among them to produce daily combined AOD shown in Fig. 1. Level 3 daily and monthly AOD from Aqua-MODIS and Terra-MODIS on a resolution of $1^{\circ} \times 1^{\circ}$ grid from 2003 to 2020 are combined to study the aerosol extremes and interannual variations.

The near-ultraviolet aerosol index (UVAI) at $340 \mathrm{~nm}$ from Tropospheric Monitoring Instrument (TROPOMI) on board the Copernicus Sentinel-5 Precursor satellite (Veefkind et al. 2012) is used to distinguish absorbing aerosols, such as dust, from non-absorbing aerosols. UVAI is widely used to study the emissions and transport of dust (e.g., Prospero et al. 2002; Ginoux and Torres 2003). Here level 2 daily data in June 2020 are aggregated into $0.25^{\circ} \times 0.25^{\circ}$ grids to study dust transport.

To examine the vertical profiles of trans-Atlantic dust plumes, daily 532-nm total attenuated backscatter (level 1) and the depolarization ratio (level 2) products during June 2020 from Cloud-Aerosol Lidar with Orthogonal Polarization (CALIOP) on board the Cloud-Aerosol Lidar and Infrared Pathfinder Satellite Observation (CALIPSO) satellite (Winker et al. 2004, 2007) are used. The depolarization ratio $(\delta)$ can be used to separate spherical and nonspherical hydrometeors (Sassen 1991). Here $\delta \geq 0.2$ is used to separate nonspherical dust from other aerosols (Li et al. 2010; Pu and Ginoux 2018b), while $0.075<\delta<0.2$ is considered a dusty marine aerosol over the ocean with a base below $2.5 \mathrm{~km}$ (i.e., within marine boundary layer) and polluted dust otherwise (Kim et al. 2018).

Table 1. Datasets and related variables used in this study.

\begin{tabular}{|c|c|c|c|c|c|c|}
\hline \multirow[b]{2}{*}{ Variable } & \multirow[b]{2}{*}{ Dataset } & \multirow[b]{2}{*}{ Version } & \multicolumn{3}{|c|}{ Resolution } & \multirow[b]{2}{*}{ Download and document links } \\
\hline & & & $\begin{array}{l}\text { Period } \\
\text { used }\end{array}$ & Temporal & $\begin{array}{l}\text { Spatial } \\
\text { (lon } \times \text { lat) }\end{array}$ & \\
\hline \multirow{3}{*}{ AOD } & Terra-MODIS & 061 & $2003-20$ & $\begin{array}{l}\text { Daily } \\
\text { Monthly }\end{array}$ & $\begin{aligned} & 10 \mathrm{~km} \times 10 \mathrm{~km} \\
& 1^{\circ} \times 1^{\circ}\end{aligned}$ & \multirow{3}{*}{ https://ladsweb.modaps.eosdis.nasa.gov/ } \\
\hline & Aqua-MODIS & 061 & $2003-20$ & $\begin{array}{l}\text { Daily } \\
\text { Monthly }\end{array}$ & $\begin{aligned} & 10 \mathrm{~km} \times 10 \mathrm{~km} \\
& 1^{\circ} \times 1^{\circ}\end{aligned}$ & \\
\hline & SNPP-VIIRS & 001 & June 2020 & Daily & $6 \mathrm{~km} \times 6 \mathrm{~km}$ & \\
\hline UVAI & TROPOMI & 1 & June 2020 & Daily & $5.5 \mathrm{~km} \times 3.5 \mathrm{~km}$ & https://disc.gsfc.nasa.gov/ \\
\hline $\begin{array}{l}\text { Backscatter and } \\
\text { depolarization ratio }\end{array}$ & CALIOP & 4.20 & June 2020 & Daily & Varying & $\begin{array}{l}\text { https://asdc.larc.nasa.gov/project/CALIPSO } \\
\text { www-calipso.larc.nasa.gov/resources }\end{array}$ \\
\hline NDVI & Terra-MODIS & 006 & $2003-20$ & $\begin{array}{l}\text { 16-day, } \\
\text { monthly }\end{array}$ & $0.05^{\circ} \times 0.05^{\circ}$ & https://modis.gsfc.nasa.gov/data/dataprod/mod13.php \\
\hline Precipitation & GPM IMERG & 06 & $2003-20$ & Daily & $0.1^{\circ} \times 0.1^{\circ}$ & https://disc.gsfc.nasa.gov/ \\
\hline $\begin{array}{l}\text { Wind, geopotential } \\
\text { height, 2-m } \\
\text { temperature }\end{array}$ & $\begin{array}{c}\text { ERA5 } \\
\text { MERRA-2 }\end{array}$ & - & $\begin{array}{l}1979-2020 \\
1980-2020\end{array}$ & $\begin{array}{l}\text { Hourly and } \\
\text { monthly }\end{array}$ & $\begin{array}{c}31 \mathrm{~km} \\
0.625^{\circ} \times 0.5^{\circ}\end{array}$ & $\begin{array}{l}\text { https://cds.climate.copernicus.eu/\#!/home } \\
\text { https://disc.gsfc.nasa.gov }\end{array}$ \\
\hline Fine dust & IMPROVE & - & 2001-19 & Every 3 days & Station & http://views.cira.colostate.edu/fed/QueryWizard/Default.aspx \\
\hline PM2.5 and AQI & EPA AQS & - & June 2020 & $\begin{array}{c}\text { Daily, every } \\
3,6,12 \text { days }\end{array}$ & Station & www.epa.gov/outdoor-air-quality-data/download-daily-data \\
\hline
\end{tabular}




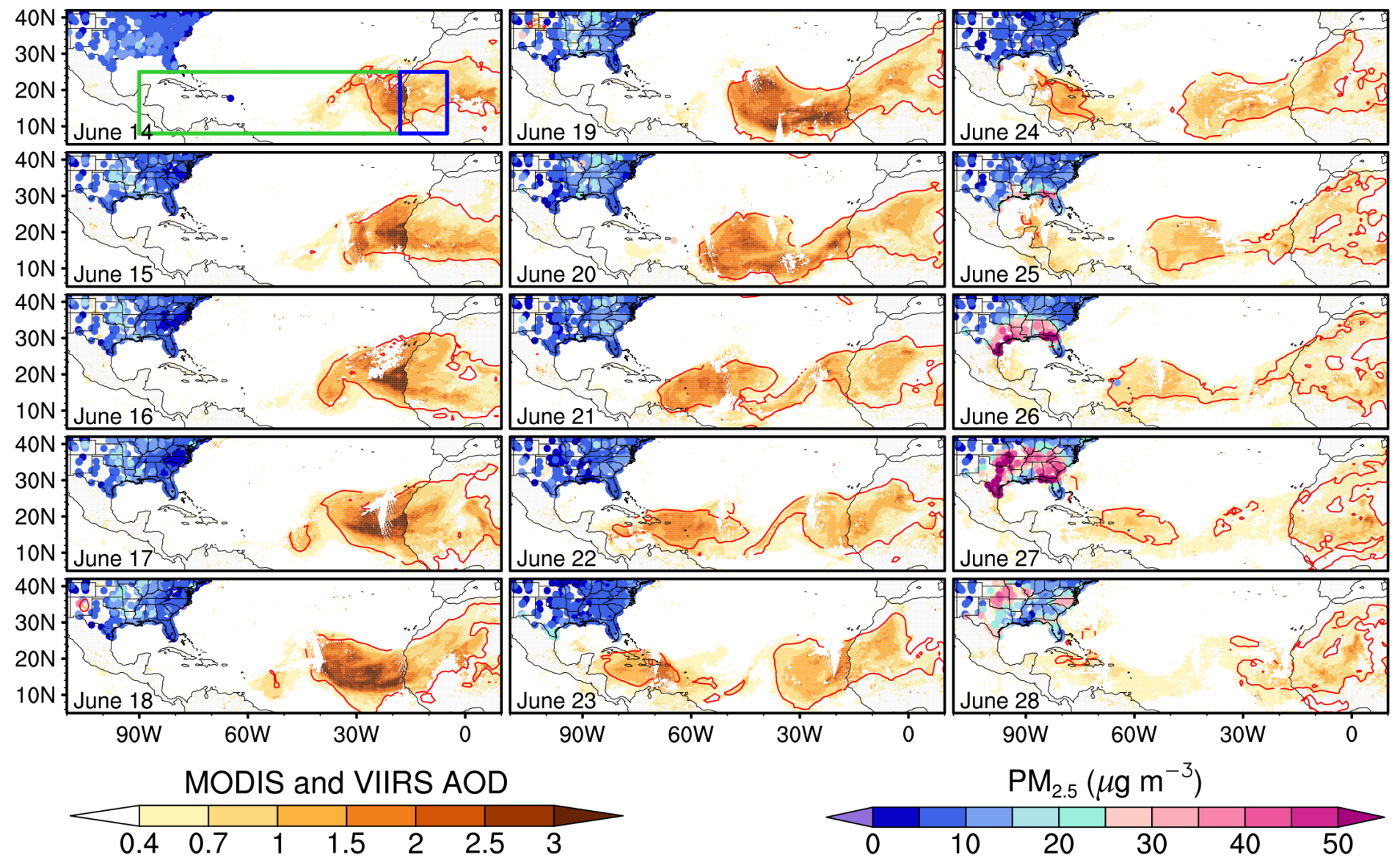

Fig. 1. Propagation of the trans-Atlantic dust plume for 14-28 June 2020. Yellow to brown shading shows the averaged aerosol optical depth (AOD) from Aqua-MODIS, Terra-MODIS, and VIIRS. Red contours denote the zero line of ultraviolet aerosol index (UVAI) from TROPOMI, above which is usually considered as absorbing aerosols such as dust. Daily PM ${ }_{2.5}$ concentrations $\left(\mu \mathrm{g} \mathrm{m}^{-3}\right)$ from EPA Air Quality System (AQS) are shown with dots. Green and blue boxes denote the averaging areas for aerosol extreme events.

Level 3 16-day and monthly normalized difference vegetation index (NDVI) retrieved from Terra-MODIS on a resolution of $0.05^{\circ} \times 0.05^{\circ}$ (collection 6; Didan 2015a,b) is used to examine connections between vegetation and dust emissions. We linearly interpolated 16-day data into daily data to examine the variations in NDVI each week during the event. The accuracy of this collection is about \pm 0.025 (https://modis-land.gsfc.nasa.gov/ValStatus.php?ProductID=MOD13).

Daily precipitation from the Integrated Multisatellite Retrievals for GPM (IMERG) Final product (level 3, version 6; Huffman et al. 2019) on a $0.1^{\circ} \times 0.1^{\circ}$ grid from 2003 to 2020 is used to examine connection between dust and precipitation. GPM IMERG is a multisatellite product using both backward and forward morphing schemes, with a calibration by Global Precipitation Climatology Centre (GPCC) monthly gauge analysis. Monthly precipitation is averaged from daily data.

EPA AQS and IMPROVE station data. U.S. Environmental Protection Agency (EPA) Air Quality System (AQS) dataset provides outdoor air quality data across the United States, Puerto Rico, and the U.S. Virgin Islands. Daily $\mathrm{PM}_{2.5}$ concentration and Air Quality Index (AQI) from AQS are used to examine the influences of the dust plume on air quality over the United States. AQI reflects the health effect of major air pollutants. Station data over Puerto Rico in June 2020 are not available at the time of our analysis.

The Interagency Monitoring of Protected Visual Environments (IMPROVE) network has collected near-surface $\mathrm{PM}_{2.5}$ samples in the United States since 1988 (Malm et al. 1994; Hand et al. 2011). This dataset has been widely used to study variations in surface fine 
dust (dust particles with aerodynamic diameter less than $2.5 \mu \mathrm{m}$ ) in the United States (e.g., Achakulwisut et al. 2017; Hand et al. 2017; Pu and Ginoux 2018b). Surface fine dust concentrations in June from 2001 to 2019 are used to form composites to examine circulation patterns associated with enhanced trans-Atlantic African dust over the United States.

ERA5 and MERRA-2 reanalyses. ERA5 (Hersbach et al. 2020) from the European Centre for Medium Range Weather Forecast (ECMWF) from 1979 to 2020 is used to study atmospheric circulation patterns associated with the trans-Atlantic dust event. Both hourly and monthly variables are used, and daily variables are averaged from hourly data. ERA5 is selected due to its high spatial resolution $(\sim 31 \mathrm{~km})$. We also conducted analysis using the Modern-Era Retrospective Analysis for Research and Applications, version 2 (MERRA-2; Gelaro et al. 2017), and the results are similar. Thus, only results from the ERA5 are presented in figures.

AEJ and CLLJ indices. To examine the relationships between trans-Atlantic dust and the African easterly jet (AEJ) and the Caribbean low-level jet (CLLJ) on the interannual time scale, jet indices are defined to represent the magnitude of the jets. The AEJ index is defined as the averaged $600 \mathrm{hPa}$ easterly wind speed over the jet core area of $10^{\circ}-15^{\circ} \mathrm{N}, 30^{\circ} \mathrm{W}-10^{\circ} \mathrm{E}$ in the ERA 5 . A higher (lower) AEJ index indicates a stronger (weaker) jet. The location of the averaging area is consistent with previous studies about the AEJ (e.g., Cook 1999; Leroux and Hall 2009). The CLLJ index is defined as the averaged easterly wind speed at $925 \mathrm{hPa}$ over $11^{\circ}-17^{\circ} \mathrm{N}$, $70^{\circ}-80^{\circ} \mathrm{W}$ based on the jet core location. The averaging area is similar to previous definitions of the CLLJ indices (e.g., Wang 2007; Martin and Schumacher 2011).

Composite analysis. To examine the typical circulation patterns associated with enhanced African dust over the southeastern United States, we applied composite analysis using the IMPROVE fine dust records in June. Six stations are selected to build two composites: days when the averaged fine dust concentrations are greater than or equal to the 75th percentile and less than or equal to the 25th percentile, respectively. VIIS1, EVER1, CHAS1, SAMA1, and OKEF1 sites are in the path of African dust onto the southeastern United States. BIBE1 is chosen to mimic the spatial pattern of enhanced $\mathrm{PM}_{2.5}$ concentrations over southern Texas during this event (Fig. 1), and results are similar if using five sites without BIBE1. Among the six sites, SAMA1 has the shortest record, available since 3 September 2000, so the composite analysis is applied during June of 2001-19. A total of 102 days are found when all six sites have data and 26 days are used for each of the composite group. Welch's $t$ test (two-tailed) is applied to examine if the differences between two composites are significant.

Multiple linear regression. Surface wind speed, vegetation coverage, and precipitation can influence dust emissions and transport (e.g., Fécan et al. 1999; Zender and Kwon 2005; Jin et al. 2021) and have been used to examine the interannual variations in dustiness in the United States and other regions (Pu and Ginoux 2017, 2018a). Here we examine how these environmental factors affect the variations in AOD over North Africa through a multiple linear regression. The regression coefficients are calculated by regressing monthly MODIS AOD in June onto standardized monthly GPM IMERG precipitation, MODIS NDVI, and ERA5 surface wind speed in June for the period of 2003-20. All the data are regridded to a $1^{\circ} \times 1^{\circ}$ grid before the calculation. The collinearity among the explanatory variables (precipitation, NDVI, and surface wind speed) is examined by calculating the variance inflation factor (VIF) (Abudu et al. 2011), and in most regions the VIF is below 2 (not shown), indicating a low collinearity (5-10 is usually considered high). Together, surface wind, vegetation, and precipitation can statistically explain about $64 \%$ of the variances of June AOD over western North Africa $\left(8^{\circ}-25^{\circ} \mathrm{N}, 5^{\circ}-18^{\circ} \mathrm{W}\right)$ from 2003 to 2020 . The unexplained variances may be 
related to nonlinear feedbacks, additional factors (e.g., mesoscale systems) affecting dust emissions, and biases in data (e.g., reanalyses may underestimate surface wind speed in Africa; Largeron et al. 2015). The reconstructed AOD anomalies are calculated by using the regression coefficients and standardized anomalies of precipitation, NDVI, and surface wind speed over three weeks (31 May-20 June) when the trans-Atlantic dust plume is not fully disconnected with African source (Fig. 1).

\section{Results}

An unprecedented trans-Atlantic dust event. A massive African dust plume swept the Caribbean and large parts of the United States in June 2020. Figure 1 shows the propagation of this trans-Atlantic dust plume from 14 to 28 June 2020. While the TROPOMI UVAI (red contour) indicates that the aerosol plume is dominated by dust, MODIS and VIIRS AOD (brownish shading) show the magnitude of the event. AOD was up to 3 off the west coast of North Africa and gradually decreased along the transport path due to deposition. When the dust plume reached the Caribbean on 21 June 2020, AOD was around 2. The strength of the plume further decreased when it arrived in the United States on 24 June. EPA station records show that $\mathrm{PM}_{2.5}$ concentrations along the Gulf coast increased during 24-28 June and reached a maximum on 27 June (Fig. 1). Over large parts of the southeastern and central United States, $\mathrm{PM}_{2.5}$ concentrations exceeded air quality guidelines set by the World Health Organization (WHO) and EPA (25 and $35 \mu \mathrm{g} \mathrm{m}^{-3}$ in $24 \mathrm{~h}$, respectively). In some places daily $\mathrm{PM}_{2.5}$ concentrations were above $50 \mu \mathrm{g} \mathrm{m}^{-3}$. AQI also reached a red level (unhealthy) in southern Texas, northern Florida, and near the Oklahoma-Arkansas border and an orange level (unhealthy for sensitive groups) in more than 11 states (Fig. ES1 in the online supplemental material). The dust plume finally dissipated on 29 June. A second African dust plume reached the eastern Caribbean around 26 June, but was much weaker. In this study, we focus on the first plume from 14-20 June to 21-27 June (viz., week 0 to week +1 ).

The magnitude of AOD associated with this event is among the strongest in boreal summer (June-August) during 2003-20. Daily AOD reached the 99th percentile over West Africa (the major dust source region in summer; Engelstaedter and Washington 2007) at the beginning of the event (14-17 June) and during the transport across the Atlantic (16-25 June; Fig. ES2). This suggests that the extreme trans-Atlantic dust plume is associated with both intensified emission and transport processes.

To further quantify how extreme this event is, we defined an aerosol extreme event (AEE), that is, when regional averaged daily MODIS AOD is greater than the 90th percentile of daily AOD centered on a 15-day window in boreal summer (June-August) during 2003-20. The duration of an AEE is defined as the number of consecutive days $(\geq 1)$ that meet the above threshold, while AEE magnitude is the mean AOD averaged over all days during the event. We focus on two areas where AOD is extremely high during this event (Fig. 1 and Fig. ES2). Over the tropical North Atlantic $\left(8^{\circ}-25^{\circ} \mathrm{N}, 18^{\circ}-90^{\circ} \mathrm{W}\right.$; green box in Fig. 1), an AEE during 15-26 June 2020 (i.e., this event) is the strongest in terms of both magnitude and duration in the past 18 years in summer (Fig. 2a). Over western North Africa $\left(8^{\circ}-25^{\circ} \mathrm{N}, 5^{\circ}-18^{\circ} \mathrm{W}\right.$; blue box in Fig. 1) the magnitude of AEE during 14-17 June is the highest for events longer than one day in the past 18 years (Fig. 2b). Also note that high AOD over the dust source region is not necessarily associated with high AOD over the tropical North Atlantic (Fig. 2), e.g., the summer of 2004, which indicates that atmospheric transport plays a critical role in the development of extreme trans-Atlantic dust events.

To understand the transport process, we first examine the vertical distribution of the dust plume using CALIOP 532-nm total attenuated backscatter (Fig. 3). Note that when dust is dense, the attenuation beneath the thick dust layer can be biased and may appear "dustfree” but actually contain some dust. Near the west coast of Africa, the dust plume was 
largely located between 2 and $6 \mathrm{~km}$ within the Saharan air layer (18 June). As the plume propagated westward, dust was largely concentrated in a layer of $2-5 \mathrm{~km}$ above the tropical North Atlantic (21 June). The whole plume sank to $0-4 \mathrm{~km}$ when it reached the central Caribbean (24 June). Such a sinking and evolution of dust-layer depth are consistent with previous studies about the Saharan air layer during its transport across the Atlantic (e.g., Braun 2010; Adams et al. 2012; Groß et al. 2015; Weinzierl et al. 2017). By the time the plume arrived at the eastern Gulf of Mexico (25 June), its strength was largely reduced. The vertical profiles of the dust plume indicate that the transport of African dust is associated with large-scale circulation systems in the middle to lower troposphere near the coast of West Africa and in the lower troposphere over the Caribbean Sea and Gulf of Mexico. The transport processes are analyzed in the following section by examining atmospheric circulation patterns at different pressure levels.

\section{Anomalous circulation patterns that} favor dust transport. The AEJ and the associated AEWs have long been related to the westward propagation of African dust across the tropical North Atlantic (e.g., Prospero and Carlson 1981; Jones et al. 2003; Schepanski et al. 2017). The AEJ is centered between 700 and $500 \mathrm{hPa}$ and peaks during (a) Aerosol extreme events (tropical North Atlantic)

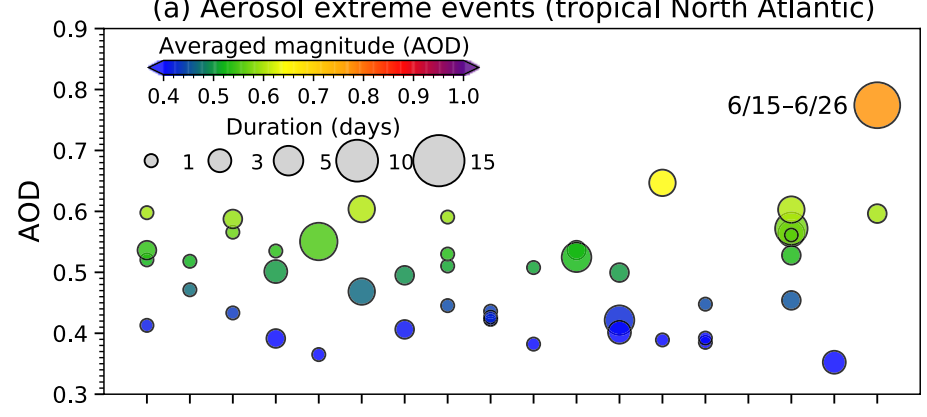

(b) Aerosol extreme events (western North Africa)

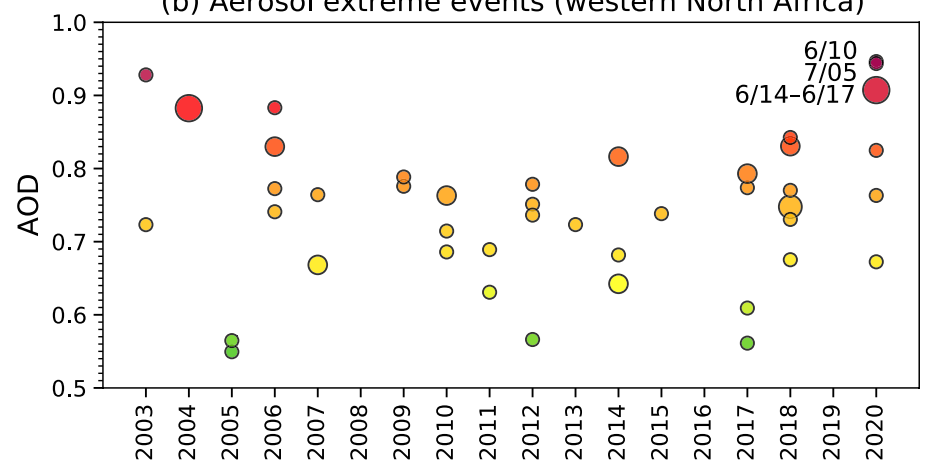

Fig. 2. Aerosol extreme events over the tropical North Atlantic and western North Africa. Magnitude and duration of extreme aerosol events over (a) the tropical North Atlantic (green box in Fig. 1; $8^{\circ}-25^{\circ} \mathrm{N}, 18^{\circ}-90^{\circ} \mathrm{W}$ ) and (b) western North Africa (blue box in Fig. $1 ; 8^{\circ}-25^{\circ} \mathrm{N}, 5^{\circ}-18^{\circ} \mathrm{W}$ ) in June-August from 2003 to 2020 . Size of the dots indicates the length of the events while colors denote the averaged magnitude. An aerosol extreme event (AEE) is defined when area-averaged daily MODIS AOD is greater than the 90th percentile of daily AOD centered on a 15-day window in boreal summer during 2003-20. The duration of an AEE is defined as the number of consecutive days $(\geq 1)$ that meet the criteria, while the magnitude is the averaged AOD during the event. The dates of the strongest events in 2020 are also shown.

boreal summer with a maximum easterly wind speed exceeding $12 \mathrm{~m} \mathrm{~s}^{-1}$ at the jet core (e.g., Cook 1999; Thorncroft and Blackburn 1999). The climatological location of the AEJ in June is shown in Fig. 4 (navy contours). Two weeks before the development of the trans-Atlantic dust plume, the AEJ was anomalously weak off the coast but anomalously strong over land between $15^{\circ} \mathrm{W}$ and $30^{\circ} \mathrm{E}$ near the jet core (Figs. $\left.4 \mathrm{a}, \mathrm{b}\right)$. The strength of the jet greatly increased during of the first week of the event (14-20 June; Fig. 4c), following a strengthening of the Saharan high over northwestern Africa (Fig. 4c and Fig. ES3c). The anomalous easterly winds between $15^{\circ} \mathrm{E}$ and $40^{\circ} \mathrm{W}$ favor the westward transport of the African dust plume (denoted by purple dots; Fig. 4c) to the eastern Atlantic. In the following week (21-27 June), the enhanced Saharan high and anomalous low geopotential height over tropical Africa $\left(5^{\circ} \mathrm{S}-15^{\circ} \mathrm{N}\right.$; Fig. ES3d) is somewhat similar to the North African dipole pattern (NAFD; Rodríguez et al. 2015), which favors anomalous easterly winds over the Sahara and enhanced westward dust export. Such a dipole pattern is also noted by a recent study of this event (Francis et al. 2020). The AEJ further intensified in this week, with anomalous easterly winds extending from the west coast of Africa to the Caribbean Sea between $5^{\circ}$ and $25^{\circ} \mathrm{N}$ (Fig. $4 \mathrm{~d}$ ). The intensified AEJ was accompanied by the development and westward propagation of the AEWs to the north of the jet core (Fig. ES4), facilitating the transport of the dust plume. 
Total Attenuated Backscatter at $532 \mathrm{~nm}\left(\mathrm{~km}^{-1} \mathrm{sr}^{-1}\right)$

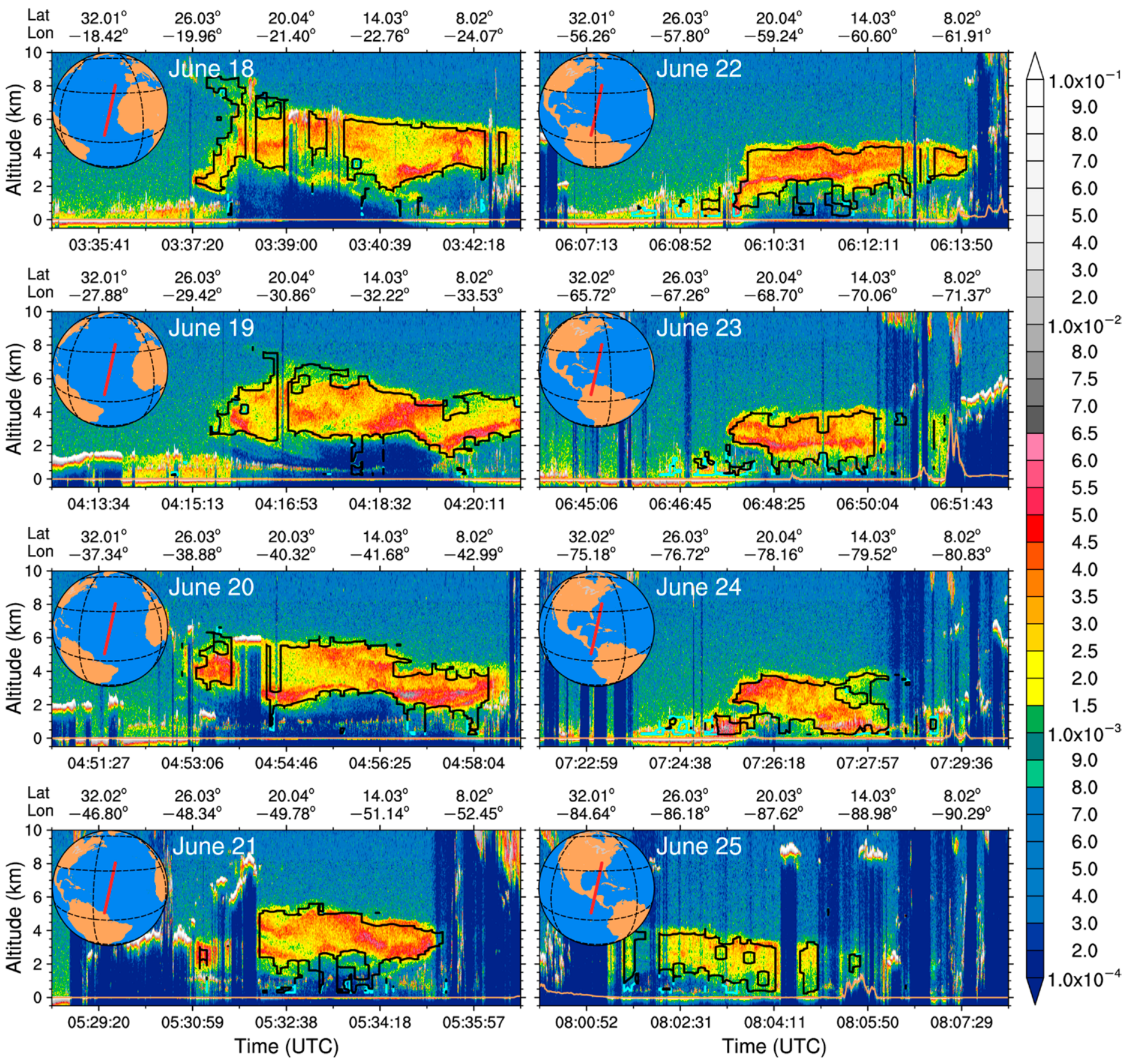

Fig. 3. CALIOP snapshots of the trans-Atlantic dust plume for 18-25 June 2020. Shading shows 532-nm total attenuated backscatter $\left(\mathrm{km}^{-1} \mathbf{s r}^{-1}\right)$. The corresponding satellite tracks (red lines) are displayed in the inset at the upper-left corner of each panel. Black contours denote dust aerosols (depolarization ratio $\geq 0.2$ ) and cyan contours denote dusty marine aerosols over the ocean where layer base is lower than $2.5 \mathrm{~km}$ and polluted dust elsewhere $(0.075<$ depolarization ratio $<0.2)$. Surface elevation is indicated by brown lines.

The positive correlation between the AEJ index and AOD over the Atlantic in June (Fig. 5a) also shows that following the strengthening of the AEJ, more African dust will be transported into the tropical North Atlantic and Caribbean Sea between $8^{\circ}$ and $25^{\circ} \mathrm{N}$. The linear relationship between the AEJ index and Atlantic AOD in late June is weakened by the extremely high values in 2020 (Fig. 5c), possibly indicating nonlinear interactions between the jet and African dust (e.g., Bercos-Hickey et al. 2017, 2020). The AEJ index in this event is actually the strongest for the weeks of 14-27 June in the past 42 years (41 years in MERRA-2; Fig. ES5) and above 
the 99th percentile of any 14-day averages during the full summer period from 1979 to 2020 (Fig. ES6). The extremely intensified AEJ and associated wave activity play a critical role in the development of the extreme dust plume over the tropical North Atlantic.

At lower levels over the central to western North Atlantic, the North Atlantic subtropical high (NASH) is anomalously strong during the event [Figs. 6a,b; 1,560-gpm contour denotes the edge of the NASH following Li et al. (2011)], with a southwestward extension toward the Gulf of Mexico and northern Caribbean in week +1 (21-27 June; Fig. 6b). The anticyclonic flow of the NASH can steer dust layers into the continental United States (Doherty et al. 2008), while the subsidence over the west part of the NASH (Li et al. 2011) favors the descending of the African dust plume during its transport over the Atlantic (Colarco et al. 2003). Accompanied by the westward extension of the NASH, the meridional pressure gradient intensified over the Caribbean Sea, and the CLLJ (e.g., Wang 2007; Cook and Vizy 2010) at $925 \mathrm{hPa}$ was enhanced (Fig. 6d). The magnitude of the CLLJ index during the week of 21-27 June is the second strongest for the week of 21-27 June over the past 42 years (the fourth in the MERRA-2; Fig. ES5). The weekly mean jet index is above the 98th percentile of any 7-day average of the CLLJ index in June-August from 1979 to 2020 (Fig. ES6). The extremely intense CLLJ favors a low-level westward transport of dust over the Caribbean Sea (Figs. 5b,d) and also tends to reduce precipitation over the Caribbean (Wang 2007), preventing the wet scavenging of dust particles.

Are the anomalous circulation patterns unique for this event? What are the favorable conditions for African dust to be transported to the United States? In summer, high con- (a) week -2 (May 31-June 6)

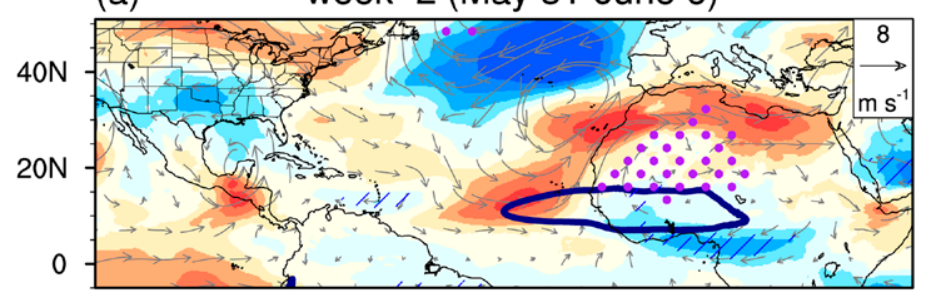

(b)

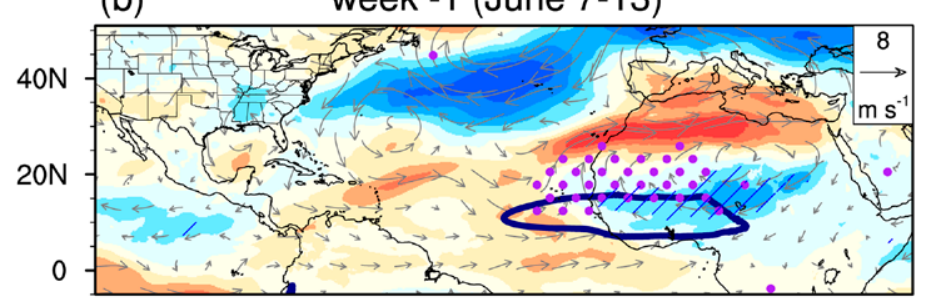

(c)

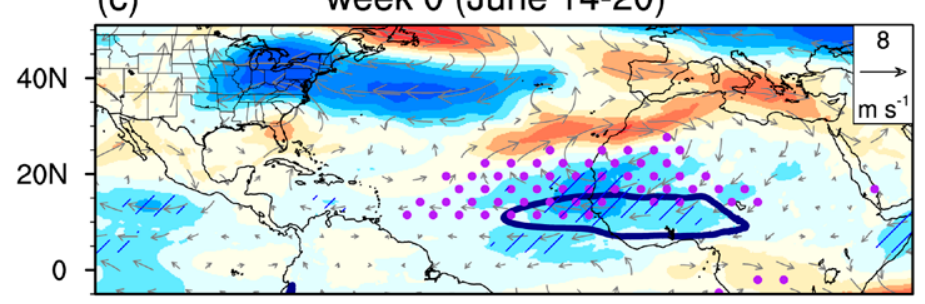

(d)

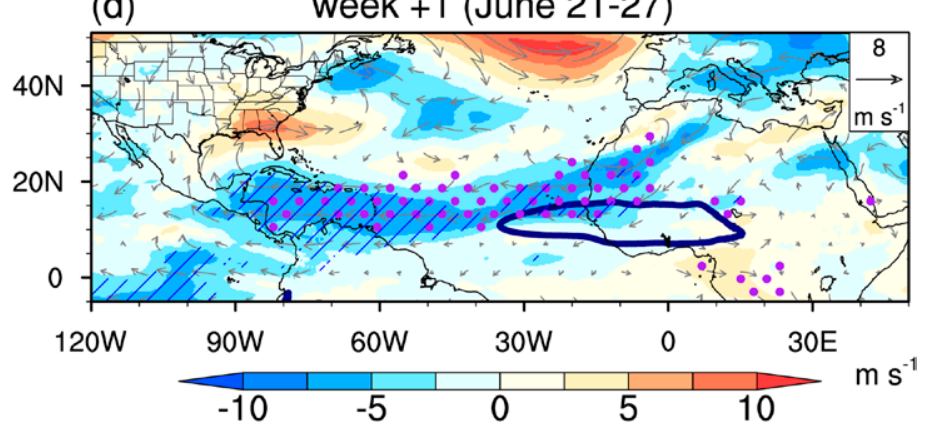

Fig. 4. Wind anomalies at $600 \mathrm{hPa}$ during 31 May-27 Jun 2020. Anomalies of 600-hPa winds (vectors; $\mathrm{m} \mathrm{s}^{-1}$ ) and zonal wind speed (shading; $\mathrm{m} \mathrm{s}^{-1}$ ) with reference to the 1979-2019 climatology in June. Negative (positive) wind speed indicates easterly (westerly) wind anomalies. Navy contours (zonal wind speed of -11 $\mathrm{m} \mathrm{s}^{-1}$ in the 1979-2019 climatology) denote the climatological location of the African easterly jet. Regions with weekly averaged AOD $\geq 0.6$ are dotted in purple. "Week -2 ," and "week -1 " denote 2 weeks and 1 week before the event, while "week 0 " and "week +1 " denote the first and second week of the event, respectively. Regions where the easterly wind speed is $\geq 90$ th percentile of zonal wind speeds (in absolute value) for that week in the past 42 years (1979-2020) are hatched in blue. centrations of fine dust over the Gulf States and the Virgin Islands have been related to transported African dust (Perry et al. 1997; Hand et al. 2017). Using the surface fine dust data from the IMPROVE network, we perform composite analysis to examine the conditions associated with high and low concentrations of surface fine dust at six sites over the southeastern and southern United States (Fig. 7) during June of 2001-19.

Figure 7 shows the differences of the two composites. Enhanced fine dust concentrations are found over large parts of the southeastern and central United States (Fig. 7a), a pattern 
(a) Correlation between AOD and AEJ Index (June)

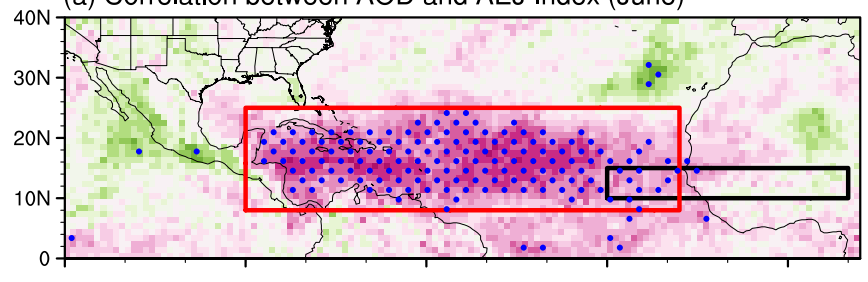

(b) Correlation between AOD and CLLJ Index (June)

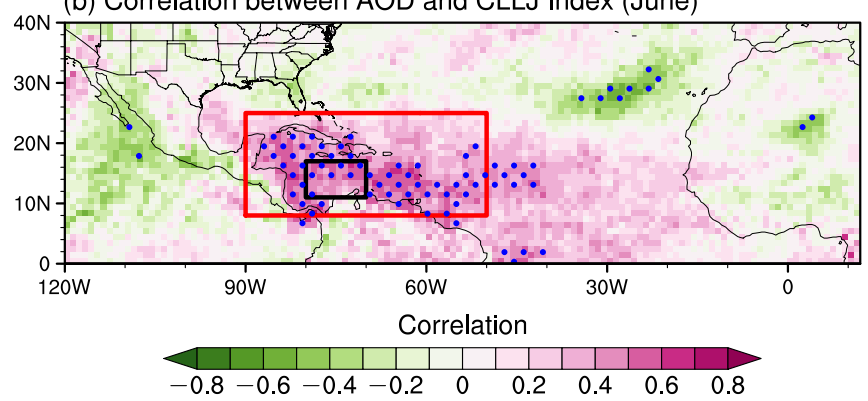

(c) June 14-27

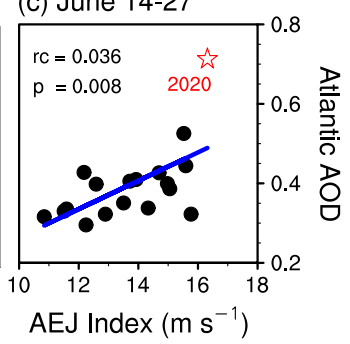

(d) June 21-27

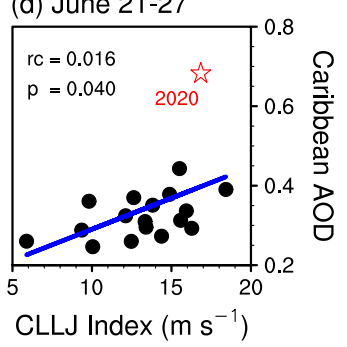

Fig. 5. Relationship between jet indices and AOD. (left) Kendall's $\tau$ correlations between monthly means of MODIS AOD and (a) the African easterly jet (AEJ) index and (b) Caribbean low-level jet (CLLJ) index in June from 2003 to 2020. Black boxes denote the averaging areas of the easterly wind speed for the AEJ and CLLJ indices. Correlations significant at the $95 \%$ confidence level (two-tailed $t$ test) are dotted in blue. (right) Scatterplot of weekly means of (c) tropical North Atlantic AOD [averaged over $8^{\circ}-25^{\circ} \mathrm{N}, 18^{\circ}-90^{\circ} \mathrm{W}$; red box in (a)] vs the AEJ index for 14-27 June and (d) Caribbean AOD (averaged over $8^{\circ}-25^{\circ} \mathrm{N}, 50^{\circ}-90^{\circ} \mathrm{W}$; red box in (b)] vs the CLLJ index for the week of $21-27$ June from 2003 to 2020 . Values in 2020 are marked by red stars.
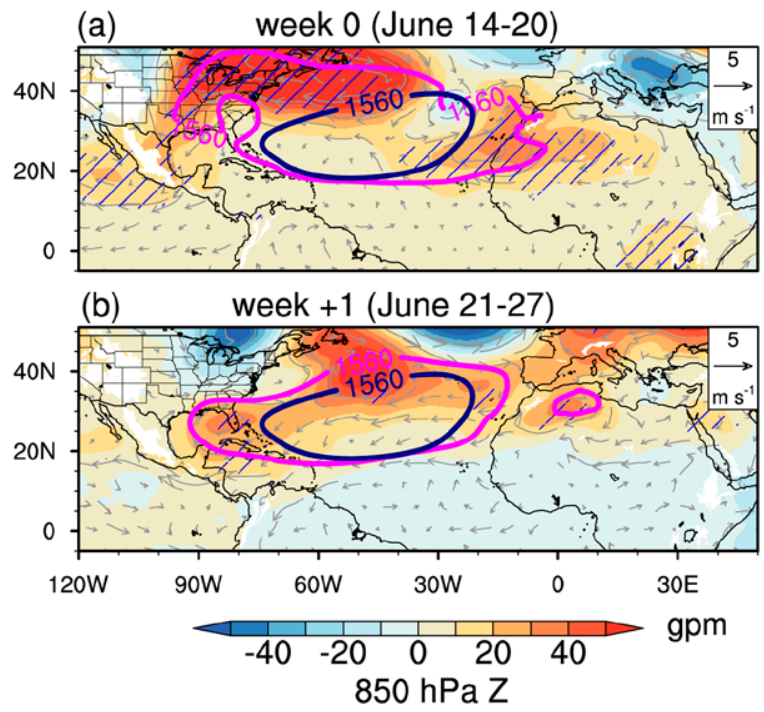

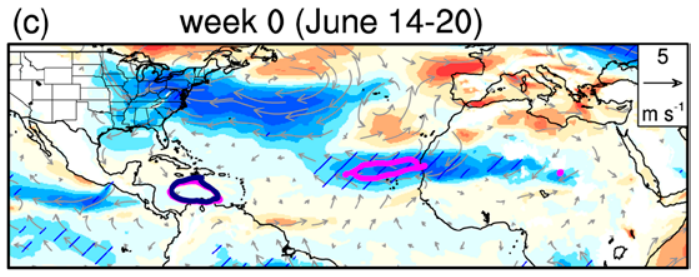

(d) week +1 (June 21-27)

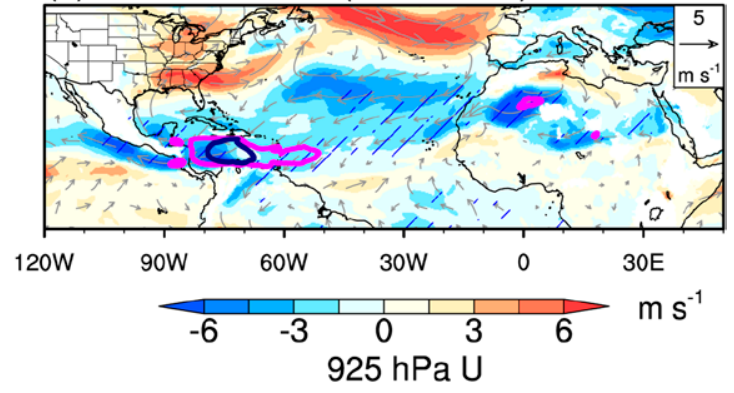

Fig. 6. Low-level circulation anomalies during the event. Anomalies of (a),(b) 850-hPa geopotential height (shading; gpm) and winds (vectors; $\mathrm{m} \mathrm{s}^{-1}$ ) and (c),(d) 925-hPa zonal wind speed (shading; negative values denote easterly wind anomalies, and positive values denote westerly wind anomalies) and winds (vectors) with reference to the 1979-2019 climatology in June. Climatological locations of the North Atlantic subtropical high (denoted by the 1,560-gpm contour) and the CLLJ (denoted by the $-12 \mathrm{~m} \mathrm{~s}^{-1}$ zonal wind speed contour) are shown in navy contours in (a) and (b) and in (c) and (d), respectively. Weekly locations of the NASH and CLLJ are shown in magenta contours. "Week 0 " and "week +1 " denote the first and second week of the event, respectively. Regions where $850-\mathrm{hPa}$ geopotential height is $\geq 90$ th percentile in (a) and (b) and $925-\mathrm{hPa}$ easterly wind speed is $\geq 90$ th percentile of zonal wind speeds (in absolute values) in (c) and (d) for each week in the past 42 years (1979-2020) are hatched in blue. 
(a)

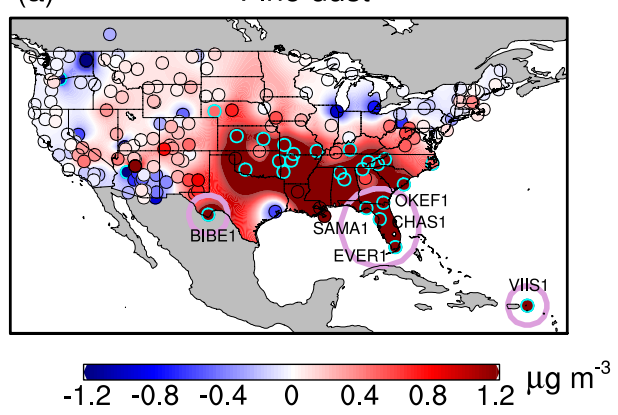

(c) $600 \mathrm{hPa}$ Geopotential height and winds

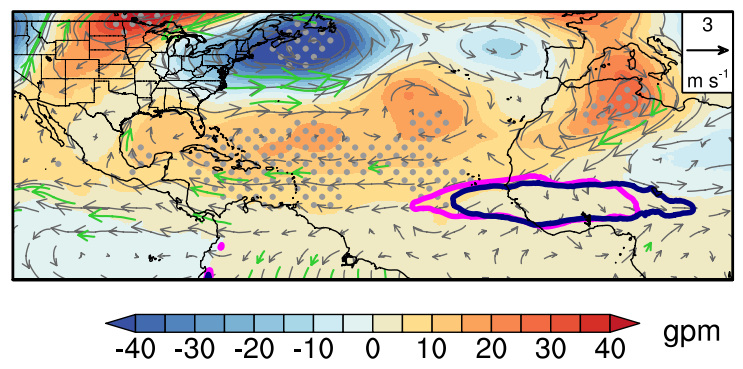

(b) $850 \mathrm{hPa}$ Geopotential height and winds

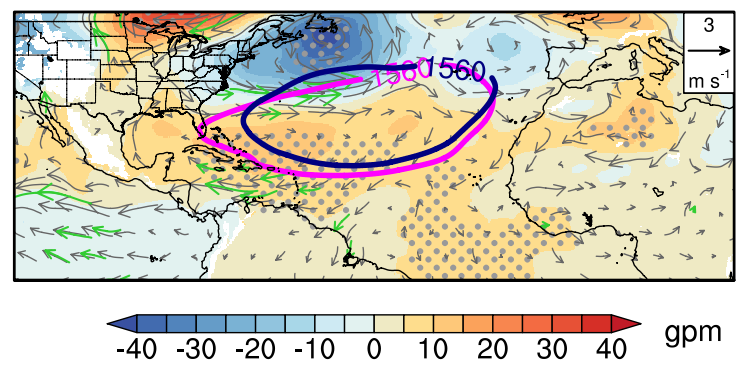

(d)

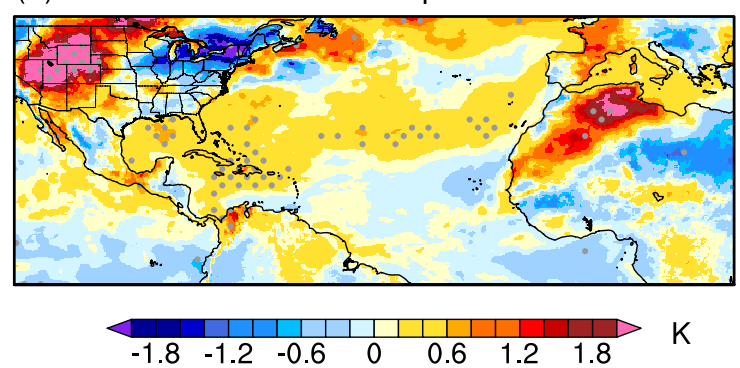

Fig. 7. Circulation and surface temperature patterns associated with enhanced surface fine dust concentrations over the southeastern United States. Differences of (a) fine dust concentrations ( $\left.\mu \mathrm{g} \mathrm{m}^{-3}\right)$, (b) 850- and (c) 600-hPa geopotential heights (shading; gpm) and winds (vectors; $\mathrm{m} \mathrm{s}^{-1}$ ), and (d) 2- $\mathrm{m}$ temperature (K) between the composites with high and low fine dust concentrations at six IMPROVE sites over the southern and southeastern United States (marked by pink circles). Shading in (a) shows gridded $\left(0.5^{\circ} \times 0.5^{\circ}\right)$ differences in surface fine dust concentrations, while station values are denoted by color dots with black circles. Station values significant at the $95 \%$ confidence level are marked by cyan circles (two-tailed $t$ test). Dotted area in (b)-(d) indicates the differences are significant at the $95 \%$ confidence level (two-tailed $t$ test). Magenta and blue contours in (b) and (c) show the locations of the NASH and AEJ in the composites with high and low fine dust concentrations, respectively.

similar to the increased $\mathrm{PM}_{2.5}$ concentrations during 27-28 June 2020 (Fig. 1). Increased fine dust concentrations are associated with a southwestward extension of the NASH and an intensified CLLJ at low level (Fig. 7b). At $600 \mathrm{hPa}$ the core of the AEJ is shifted westward associated with a strengthened Saharan high over northern Africa, while the anomalous easterlies over North Africa and the tropical North Atlantic favor the emission and transport of African dust to the Caribbean and the United States (Fig. 7c).

The intensification of the Saharan high is largely associated with anomalously high surface temperature over northern Africa (Fig. 7d), which increases the meridional temperature gradient between the warm Sahara and cool Guinean coast, a key factor that determines the strength and location of the AEJ (e.g., Cook 1999; Raj et al. 2019). A similar warming in western North Africa centered over $15^{\circ}-30^{\circ} \mathrm{N}$ is also found in this event from week 0 to week +1 (Fig. ES7), enhancing the Saharan high and the AEJ.

Enhanced dust emissions over western North Africa. Surface wind speed is one of the dominant factors affecting dust emissions in North Africa (e.g., Ridley et al. 2014; Evan et al. 2016). We found that $10-\mathrm{m}$ wind speed is intensified (Figs. $8 \mathrm{a}-\mathrm{d}$ ) before and during the event over major dust source regions in West Africa $\left(15^{\circ}-25^{\circ} \mathrm{N}, 10^{\circ} \mathrm{W}-5^{\circ} \mathrm{E}\right.$, e.g., in Mauritania, Mali, and Algeria) (Prospero et al. 2002; Engelstaedter and Washington 2007; Ginoux et al. 2012a). The finding is consistent with Francis et al. (2020), who found that strong northeasterly winds over the Sahara caused continuous dust emissions during this event. The magnitude of the surface wind speeds near the dust source regions 2 weeks before (31 May-13 June) and at the 
(a) week -2 (May 31-June 6)

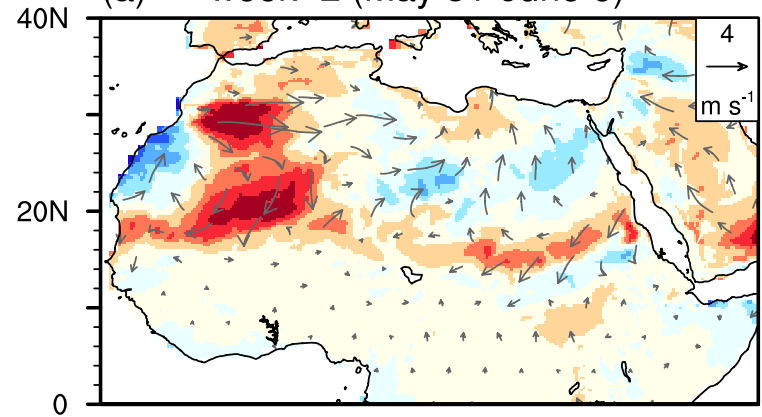

(b) week -1 (June 7-13)

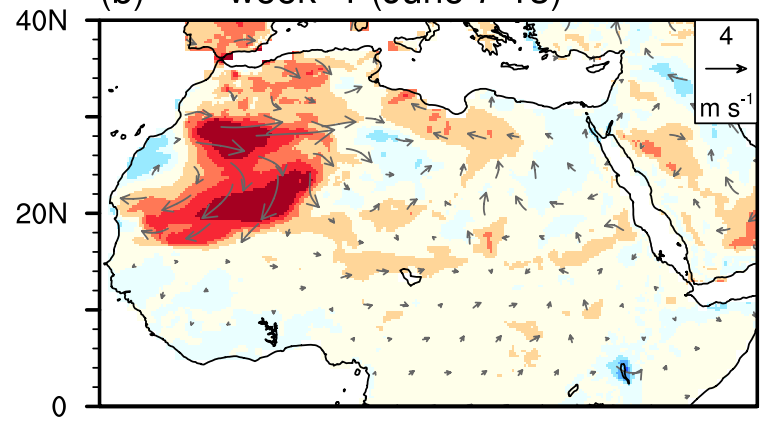

(c) week 0 (June 14-20)

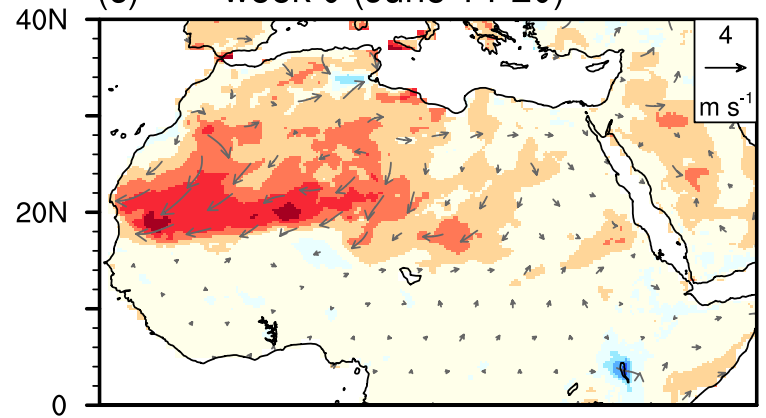

(d) week +1 (June 21-27)

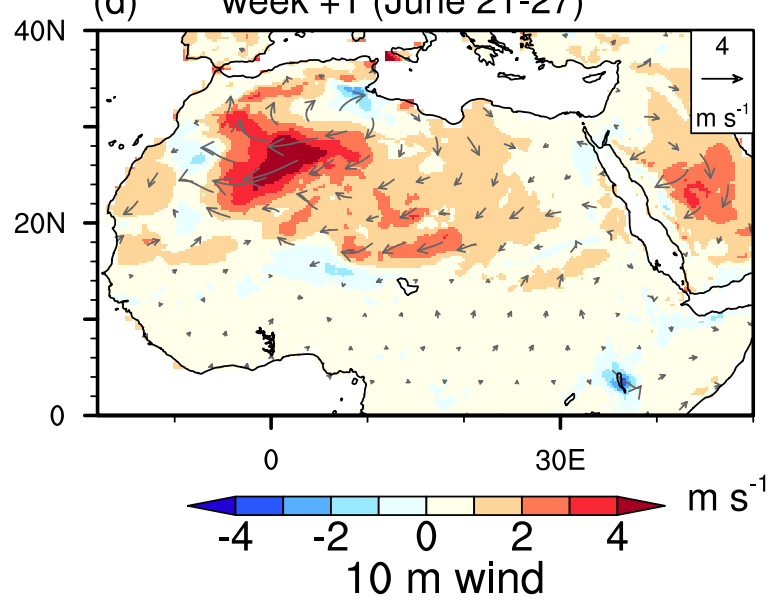

(e) week -2 (May 31-June 6)

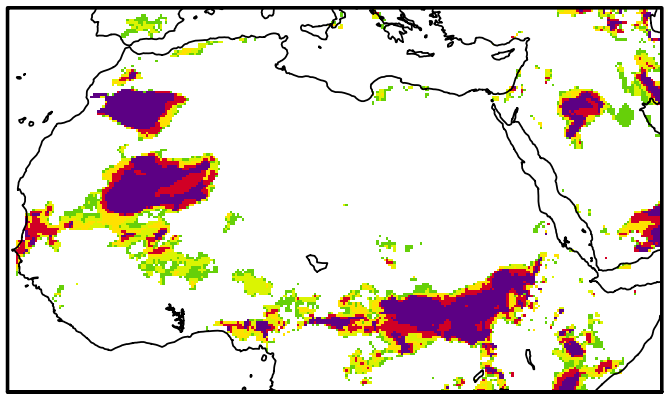

(f) week -1 (June 7-13)

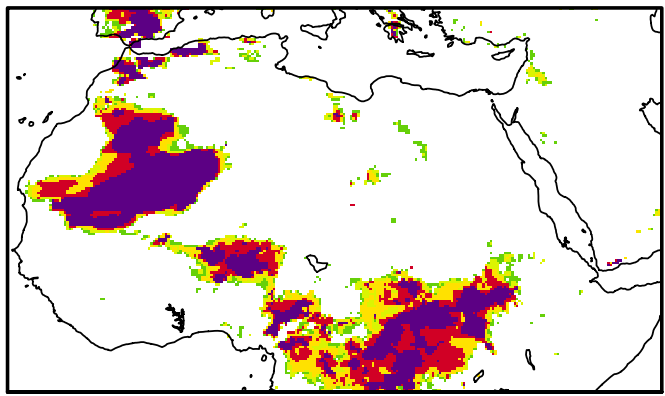

(g) week 0 (June 14-20)

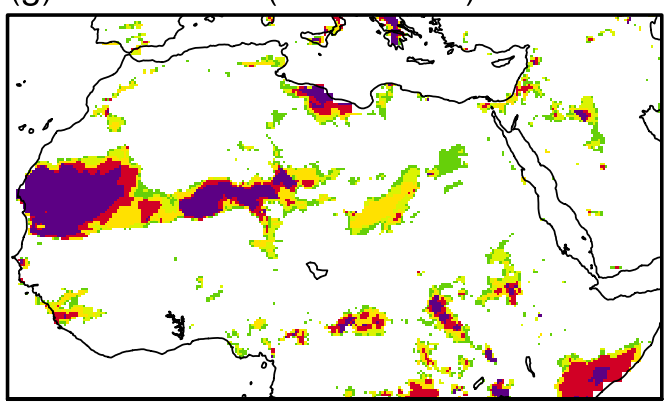

(h) week +1 (June 21-27)

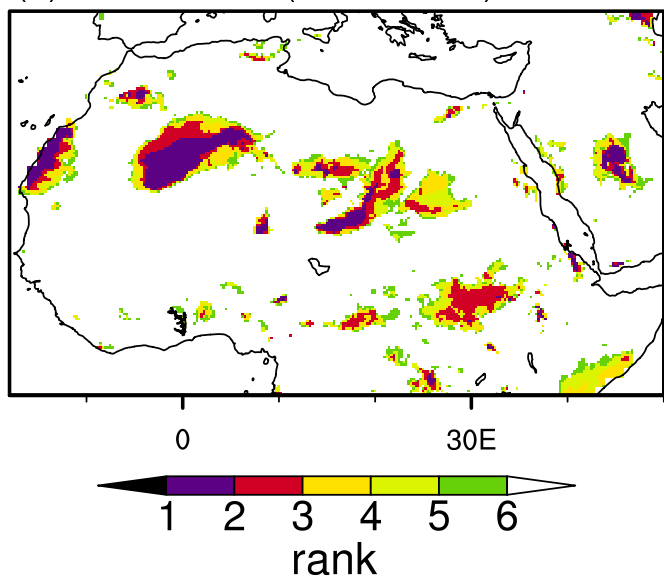

Fig. 8. Surface wind speed and rank. (a)-(d) Anomalies of surface 10-m wind speed (shading; $\mathrm{m} \mathrm{s}^{-1}$ ) and wind vectors with reference to the 1979-2019 climatology in June. (e)-(h) The rank of surface wind speed from 1 (purple) to 5 (green) during 1979-2020, e.g., rank 1 (2) indicates that wind speed at the grid point is the strongest (second strongest) for the week in the past $\mathbf{4 2}$ years.

beginning of the westward propagation of the dust plume (14-20 June) are the strongest (or among the top five) for each of the week during 1979-2020 (Figs. 8e-g), largely facilitating the emission and transport of dust.

In addition to surface wind speed, vegetation and precipitation have also been related to dust emissions in this region (e.g., Moulin and Chiapello 2004; Mahowald et al. 2010; 
(a)

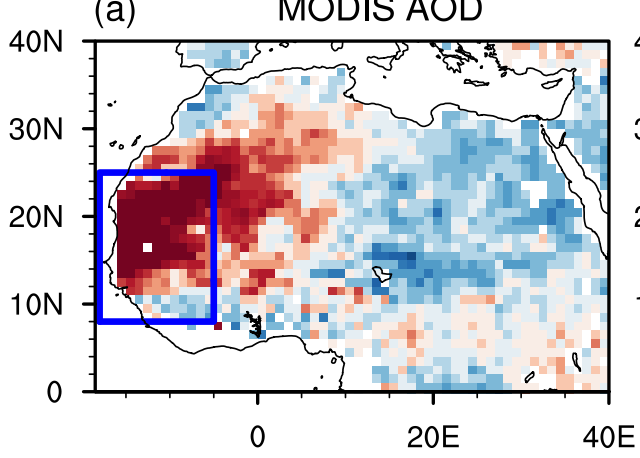

(b) Rec_AOD (All)

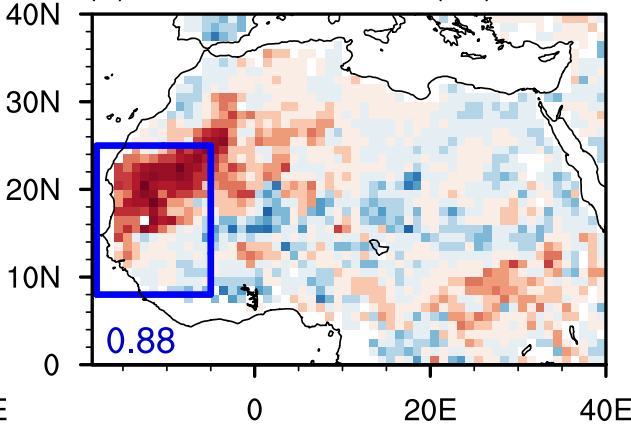

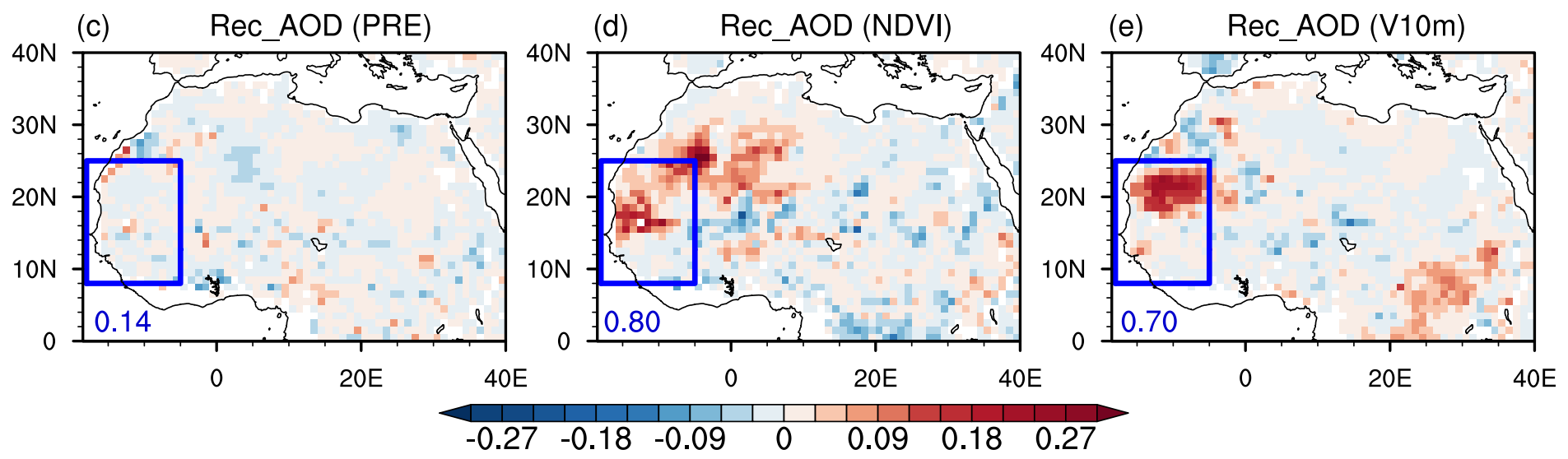

Fig. 9. Observed and reconstructed AOD anomalies (with reference to the 2003-20 mean) averaged over 31 May-20 Jun 2020. (a) MODIS AOD and (b) reconstructed AOD (Rec_AOD) and each of its components contributed by (c) precipitation (PRE), (d) NDVI, and (e) surface wind speed (V10m) averaged during 31 May-20 Jun 2020, i.e., from week -2 to week +1, when the trans-Atlantic dust plume is not fully disconnected with African source. The blue box is the averaging region for the aerosol extreme event in Fig. $2 b$. The pattern correlation (uncentered) between the reconstructed and MODIS AOD anomalies in the blue box is shown at the bottom left of each plot.

$\mathrm{Pu}$ and Ginoux 2018a). Do they play roles in this event? Using a multiple linear regression model [similar to Pu and Ginoux (2017), except bareness is replaced by NDVI], we found that other than surface wind, reduced vegetation coverage (denoted by MODIS NDVI) over the western Sahel also contribute to the increased AOD over western North Africa, while precipitation has a negligible impact (Fig. 9). A decrease in vegetation leaves soil unprotected and more susceptible to wind erosion. However, we also note that the absolute value of NDVI anomaly is quite small to the north of $15^{\circ} \mathrm{N}$ (Fig. ES8), close to the uncertainty range of the data, indicating that the NDVI change from the northern Sahel to Sahara is less reliable and may be contaminated by soil noise (Huete et al. 2002). Increased surface wind speed and reduced vegetation contribute to less than half of the observed AOD anomaly in this event (Fig. 9), suggesting other factors, e.g., mesoscale convections, may also play important roles in enhancing African dust emissions.

\section{Discussion.}

The long-range transport of an African dust plume in late June 2020 significantly degraded air quality over the Caribbean Basin and the central and southeastern United States. We found that this record-breaking trans-Atlantic dust event is associated with both extremely enhanced dust emissions in western North Africa and large-scale circulation extremes that favor longrange dust transport. While the unprecedented surface wind speed (the strongest in the past 42 years for the weeks of 31 May-6 June, 7-13 June, and 14-20 June) increased dust emissions in Africa, the intensified AEJ (the strongest in the past 42 years for 14-27 June), the westward extension of the NASH and enhanced CLLJ (the second strongest since 1979 for 21-27 June) 
systematically favor the westward transport of African dust at different vertical levels. A strong AEJ supports the development and propagation of the AEWs (Leroux and Hall 2009), which transport the African dust toward the Caribbean in the middle to lower troposphere. The westward extension of the NASH intensifies the easterly CLLJ, further steering the shallower, descended dust layer over the Caribbean toward the continental United States at low level. While the atmospheric circulation anomalies in this event are similar to the typical circulation patterns that favor the transport of African dust to the United States, the magnitudes of the midtroposphere and low-level jets and surface wind anomalies are exceptional, highlighting a substantial contribution of atmospheric circulation to this extreme trans-Atlantic dust event.

Will there be more similar events in the future? The 2020 trans-Atlantic dust event is associated with both enhanced dust emissions and long-range transport. Therefore, we argue that future variations in trans-Atlantic dust event also largely rely on two factors: changes in African dust emissions and atmospheric conditions that control dust transport. Climate models have projected 1) an enhanced AEJ (Raj et al. 2019) and stronger AEWs to the north of the jet core (Skinner and Diffenbaugh 2014) due to a strengthened meridional surface temperature gradient between the Guinean coast and the Sahara, 2) an intensified and westward-extended NASH due to sharper land-sea heating contrasts (Li et al. 2012), and 3) an intensified CLLJ (Taylor et al. 2013; Corrales-Suastegui et al. 2020) in the late twentyfirst century. The projected changes in circulation patterns generally favor the westward transport of African dust to the Caribbean Basin and the United States, indicating that more trans-Atlantic dust events are likely to occur in the future if dust emissions do not change. On the other hand, model simulations and projections of African dust emissions still have large uncertainties (Huneeus et al. 2011; Kim et al. 2014; Pu and Ginoux 2018a; Wu et al. 2020). Observational studies found an expansion of the Sahara Desert over the twentieth century that can be linked to long-term decreasing trends in precipitation (Thomas and Nigam 2018), while studies based on model results indicate either an overall decrease in dust emissions in the Sahara (Evan et al. 2016; Yuan et al. 2020) or an increase in southern Sahara in boreal summer (Pu and Ginoux 2018a) due to climate change at the end of the twenty-first century. In addition, changes in anthropogenic land use in the Sahel, such as overgrazing, cultivation, and deforestation, also affect dust emissions (Mulitza et al. 2010; Ginoux et al. 2012b), adding uncertainties to future projections of African dust emissions. Therefore, uncertainties in modeling a series of physical processes in dust life cycle largely hinder reliable projections of trans-Atlantic dust extremes in the future. Climate change induced variations in African dust transport would also affect downwind regions not limited to areas discussed here, such as South America. Changes in dust emissions and transport in turn would feedback to the climate system via modifying local radiative balance and cloud processes. Given the importance of African dust in regional climate, environment, and public health, future studies that improve the projection of African dust emissions and transport will greatly benefit climate and air quality projections in dust source and downwind regions.

Acknowledgments. IMPROVE is a collaborative association of state, tribal, and federal agencies and international partners. The U.S. Environmental Protection Agency is the primary funding source, with contracting and research support from the National Park Service. The Air Quality Group at the University of California, Davis, is the central analytical laboratory, with ion analysis provided by Research Triangle Institute, and carbon analysis provided by Desert Research Institute. The valuable comments from three anonymous reviewers and the editor improved the paper and are gratefully appreciated. We also thank David Rahn for helpful comments on the manuscript.

Data availability statement. All datasets used in this study can be downloaded from websites listed in Table 1. 
Abudu, S., C. L. Cui, J. P. King, J. Moreno, and A. S. Bawazir, 2011: Modeling of daily pan evaporation using partial least squares regression. Sci. China Technol. Sci., 54, 163-174, https://doi.org/10.1007/s11431-010-4205-z.

Achakulwisut, P., L. Shen, and L. J. Mickley, 2017: What controls springtime fine dust variability in the western United States? Investigating the 2002-2015 increase in fine dust in the US southwest. J. Geophys. Res. Atmos., 122, 12 449-12 467, https://doi.org/10.1002/2017JD027208.

Adams, A. M., J. M. Prospero, and C. D. Zhang, 2012: CALIPSO-derived threedimensional structure of aerosol over the Atlantic Basin and adjacent continents. J. Climate, 25, 6862-6879, https://doi.org/10.1175/JCLI-D-11-00672.1.

Bercos-Hickey, E., T. R. Nathan, and S. H. Chen, 2017: Saharan dust and the African easterly jet-African easterly wave system: Structure, location and energetics. Quart. J. Roy. Meteor. Soc., 143, 2797-2808, https://doi. org/10.1002/qj.3128.

$\longrightarrow,-$, and _ -2020 : On the relationship between the African easterly jet, Saharan mineral dust aerosols, and West African precipitation. J. Climate, 33, 3533-3546, https://doi.org/10.1175/JCLI-D-18-0661.1.

Braun, S. A., 2010: Reevaluating the role of the Saharan air layer in Atlantic tropical cyclogenesis and evolution. Mon. Wea. Rev., 138, 2007-2037, https://doi. org/10.1175/2009MWR3135.1.

Bristow, C. S., K. A. Hudson-Edwards, and A. Chappell, 2010: Fertilizing the Amazon and equatorial Atlantic with West African dust. Geophys. Res. Lett., 37, L14807, https://doi.org/10.1029/2010GL043486.

Carlson, T. N., and J. Prospero, 1972: The large-scale movement of Saharan air outbreaks over the northern equatorial Atlantic. J. Appl. Meteor., 11, 283297, https://doi.org/10.1175/1520-0450(1972)011<0283:TLSMOS>2.0.C0;2.

Chen, S. P., C. H. Lu, J. McQueen, and P. Lee, 2018: Application of satellite observations in conjunction with aerosol reanalysis tor to characterize long-range transport of African and Asian dust on air quality in the contiguous US. Atmos. Environ., 187, 174-195, https://doi.org/10.1016/j.atmosenv.2018.05.038.

Colarco, P. R., and Coauthors, 2003: Saharan dust transport to the Caribbean during PRIDE: 2. Transport, vertical profiles, and deposition in simulations of in situ and remote sensing observations. J. Geophys. Res., 108, 8590, https:// doi.org/10.1029/2002JD002659.

Cook, K. H., 1999: Generation of the African easterly jet and its role in determining West African precipitation. J. Climate, 12, 1165-1184, https://doi. org/10.1175/1520-0442(1999)012<1165:GOTAEJ>2.0.C0;2.

— its relationship to precipitation. J. Climate, 23, 1477-1494, https://doi. org/10.1175/2009JCLI3210.1.

Corrales-Suastegui, A., R. Fuentes-Franco, and E. G. Pavia, 2020: The mid-summer drought over Mexico and Central America in the 21st century. Int. J. Climatol., 40, 1703-1715, https://doi.org/10.1002/joc.6296.

Didan, K., 2015a: MOD13C1 MODIS/Terra Vegetation Indices 16-Day L3 Global 0.05Deg CMG V006. NASA EOSDIS Land Processes DAAC, accessed September 2020, https://doi.org/10.5067/MODIS/MOD13C1.006.

- 2015b: MOD13C2 MODIS/Terra Vegetation Indices Monthly L3 Global 0.05Deg CMG V006. NASA EOSDIS Land Processes DAAC, accessed September 2020, https://doi.org/10.5067/MODIS/MOD13C2.006.

Doherty, 0. M., N. Riemer, and S. Hameed, 2008: Saharan mineral dust transport into the Caribbean: Observed atmospheric controls and trends. J. Geophys. Res., 113, D07211, https://doi.org/10.1029/2007JD009171.

$\longrightarrow,-$, and _ 2014: Role of the convergence zone over West Africa in controlling Saharan mineral dust load and transport in the boreal summer. Tellus, 66B, 23191, https://doi.org/10.3402/tellusb.v66.23191.

Dunion, J. P., 2011: Rewriting the climatology of the tropical North Atlantic and Caribbean Sea atmosphere. J. Climate, 24, 893-908, https://doi. org/10.1175/2010JCLI3496.1.

— tropical cyclone activity. Bull. Amer. Meteor. Soc., 85, 353-366, https://doi. org/10.1175/BAMS-85-3-353.
Engelstaedter, S., and R. Washington, 2007: Atmospheric controls on the annual cycle of North African dust. J. Geophys. Res., 112, D03103, https://doi. org/10.1029/2006JD007195.

_ I. Tegen, and R. Washington, 2006: North African dust emissions and transport. Earth-Sci. Rev., 79, 73-100, https://doi.org/10.1016/j.earscirev.2006.06.004.

Evan, A. T., J. Dunion, J. A. Foley, A. K. Heidinger, and C. S. Velden, 2006: New evidence for a relationship between Atlantic tropical cyclone activity and African dust outbreaks. Geophys. Res. Lett., 33, L19813, https://doi. org/10.1029/2006GL026408.

- C. Flamant, M. Gaetani, and F. Guichard, 2016: The past, present and future of African dust. Nature, 531, 493-495, https://doi.org/10.1038/nature17149.

Evans, S., S. Malyshev, P. Ginoux, and E. Shevliakova, 2019: The impacts of the dust radiative effect on vegetation growth in the Sahel. Global Biogeochem. Cycles, 33, 1582-1593, https://doi.org/10.1029/2018GB006128.

Fécan, F., B. Marticorena, and G. Bergametti, 1999: Parametrization of the increase of the aeolian erosion threshold wind friction velocity due to soil moisture for arid and semi-arid areas. Ann. Geophys., 17, 149-157, https://doi. org/10.1007/s00585-999-0149-7.

Francis, D., R. Fonseca, N. Nelli, J. Cuesta, M. Weston, A. Evan, and M. Temimi, 2020: The atmospheric drivers of the major Saharan dust storm in June 2020. Geophys. Res. Lett., 47, e2020GL090102, https://doi.org/10.1029/2020GL090102.

Gelaro, R., and Coauthors, 2017: The Modern-Era Retrospective Analysis for Research and Applications, version 2 (MERRA-2). J. Climate, 30, 5419-5454, https://doi.org/10.1175/JCLI-D-16-0758.1.

Ginoux, P., and O. Torres, 2003: Empirical TOMS index for dust aerosol: Applications to model validation and source characterization. J. Geophys. Res., 108, 4534, https://doi.org/10.1029/2003JD003470.

— , J. M. Prospero, T. E. Gill, N. C. Hsu, and M. Zhao, 2012a: Global-scale attribution of anthropogenic and natural dust sources and their emission rates based on MODIS deep blue aerosol products. Rev. Geophys., 50, RG3005, https://doi.org/10.1029/2012RG000388.

— L. Clarisse, C. Clerbaux, P. F. Coheur, O. Dubovik, N. C. Hsu, and M. Van Damme, 2012b: Mixing of dust and NH3 observed globally over anthropogenic dust sources. Atmos. Chem. Phys., 12, 7351-7363, https://doi.org/10.5194/ acp-12-7351-2012.

Groß, S., V. Freudenthaler, K. Schepanski, C. Toledano, A. Schafler, A. Ansmann, and B. Weinzierl, 2015: Optical properties of long-range transported Saharan dust over Barbados as measured by dual-wavelength depolarization Raman lidar measurements. Atmos. Chem. Phys., 15, 11 067-11 080, https://doi. org/10.5194/acp-15-11067-2015.

Haarig, M., and Coauthors, 2017: Triple-wavelength depolarization-ratio profiling of Saharan dust over Barbados during SALTRACE in 2013 and 2014. Atmos. Chem. Phys., 17, 10 767-10 794, https://doi.org/10.5194/acp-17-10767-2017.

Hand, J. L., and Coauthors, 2011: Spatial and seasonal patterns and temporal variability of haze and its constituents in the United States. IMPROVE Rep. 5, 207 pp., accessed September 2020, http://vista.cira.colostate.edu/Improve/improve-reports/.

_ , T. E. Gill, and B. A. Schichtel, 2017: Spatial and seasonal variability in fine mineral dust and coarse aerosol mass at remote sites across the United States. J. Geophys. Res. Atmos., 122, 3080-3097, https://doi.org/10.1002/2016JD026290.

Hersbach, H., and Coauthors, 2020: The ERA5 global reanalysis. Quart. J. Roy. Meteor. Soc., 146, 1999-2049, https://doi.org/10.1002/qj.3803.

Holben, B. N., and Coauthors, 1998: AERONET—A federated instrument network and data archive for aerosol characterization. Remote Sens. Environ., 66, 1-16, https://doi.org/10.1016/S0034-4257(98)00031-5.

_- and Coauthors, 2001: An emerging ground-based aerosol climatology: Aerosol optical depth from AERONET. J. Geophys. Res., 106, 12 067-12 097, https://doi.org/10.1029/2001JD900014.

Hsu, N. C., J. Lee, A. M. Sayer, W. Kim, C. Bettenhausen, and S. C. Tsay, 2019: VIIRS deep blue aerosol products over land: Extending the EOS long-term aerosol data records. J. Geophys. Res. Atmos., 124, 4026-4053, https://doi. org/10.1029/2018JD029688. 
Huete, A., K. Didan, T. Miura, E. P. Rodriguez, X. Gao, and L. G. Ferreira, 2002: Overview of the radiometric and biophysical performance of the MODIS vegetation indices. Remote Sens. Environ., 83, 195-213, https://doi.org/10.1016/ S0034-4257(02)00096-2.

Huffman, G., E. F. Stocker, D. T. Bolvin, E. J. Nelkin, and J. Tan, 2019: GPM IMERG Late Precipitation L3 1 day 0.1 degree $\times 0.1$ degree V06. Goddard Earth Sciences Data and Information Services Center (GES DISC), accessed September 2020, https://doi.org/10.5067/GPM/IMERGDL/DAY/06.

Huneeus, N., and Coauthors, 2011: Global dust model intercomparison in AeroCom phase I. Atmos. Chem. Phys., 11, 7781-7816, https://doi.org/10.5194/acp-117781-2011.

Jin, Q., J. Wei, W. Lau, B. Pu, and C. Wang, 2021: Interactions of Asian mineral dust with Indian summer monsoon: Recent advances and challenges. Earth-Sci. Rev., 215, 103562, https://doi.org/10.1016/j.earscirev.2021.103562.

Jones, C., N. Mahowald, and C. Luo, 2003: The role of easterly waves on African desert dust transport. J. Climate, 16, 3617-3628, https://doi.org/10.1175/15200442(2003)016<3617:TROEWO>2.0.C0;2.

Karyampudi, V. M., and T. N. Carlson, 1988: Analysis and numerical simulations of the Saharan air layer and its effect on easterly wave disturbances. J. Atmos. Sci., 45, 3102-3136, https://doi.org/10.1175/1520-0469(1988)045<3102:AA NSOT $>2.0 . C 0 ; 2$.

_ tropical cyclogenesis over the eastern Atlantic. Mon. Wea. Rev., 130, 3100 3128, https://doi.org/10.1175/1520-0493(2002)130<3100:SSIOTS>2.0.C0;2.

Kim, D., and Coauthors, 2014: Sources, sinks, and transatlantic transport of North African dust aerosol: A multimodel analysis and comparison with remote sensing data. J. Geophys. Res. Atmos., 119, 6259-6277, https://doi. org/10.1002/2013JD021099.

Kim, M. H., and Coauthors, 2018: The CALIPSO version 4 automated aerosol classification and lidar ratio selection algorithm. Atmos. Meas. Tech., 11, 61076135, https://doi.org/10.5194/amt-11-6107-2018.

Largeron, Y., F. Guichard, D. Bouniol, F. Couvreux, L. Kergoat, and B. Marticorena, 2015: Can we use surface wind fields from meteorological reanalyses for Sahelian dust emission simulations? Geophys. Res. Lett., 42, 2490-2499, https://doi.org/10.1002/2014GL062938.

Leroux, S., and N. M. J. Hall, 2009: On the relationship between African easterly waves and the African easterly jet. J. Atmos. Sci., 66, 2303-2316, https://doi. org/10.1175/2009JAS2988.1.

Li, F. Y., P. Ginoux, and V. Ramaswamy, 2010: Transport of Patagonian dust to Antarctica.J.Geophys.Res., 115,D18217, https://doi.org/10.1029/2009JD012356.

Li, W. H., L. F. Li, R. Fu, Y. Deng, and H. Wang, 2011: Changes to the North Atlantic subtropical high and its role in the intensification of summer rainfall variability in the southeastern United States. J. Climate, 24, 1499-1506, https://doi. org/10.1175/2010JCLI3829.1.

_ _ - M. F. Ting, and Y. M. Liu, 2012: Intensification of Northern Hemisphere subtropical highs in a warming climate. Nat. Geosci., 5, 830-834, https://doi.org/10.1038/ngeo1590.

Mahowald, N. M., and Coauthors, 2010: Observed 20th century desert dust variability: Impact on climate and biogeochemistry. Atmos. Chem. Phys., 10, 10875-10893, https://doi.org/10.5194/acp-10-10875-2010.

Malm, W. C., J. F. Sisler, D. Huffman, R. A. Eldred, and T. A. Cahill, 1994: Spatial and seasonal trends in particle concentration and optical extinction in the UnitedStates. J. Geophys. Res., 99, 1347-1370, https://doi.org/10.1029/93JD02916.

Martin, E. R., and C. Schumacher, 2011: The Caribbean low-level jet and its relationship with precipitation in IPCC AR4 models. J. Climate, 24, 5935-5950, https://doi.org/10.1175/JCLI-D-11-00134.1.

Meng, L., H. W. Gao, Y. Yu, X. H. Yao, Y. Gao, C. Zhang, and L. Fang, 2017: A new approach developed to study variability in North African dust transport routes over the Atlantic during 2001-2015. Geophys. Res. Lett., 44, 10026-10035, https://doi.org/10.1002/2017GL074478.

Miller, R. L., and I. Tegen, 1998: Climate response to soil dust aerosols. J. Climate, 11, 3247-3267, https://doi.org/10.1175/1520-0442(1998)011<3247:CRTSD $\mathrm{A}>2.0 . \mathrm{CO} ; 2$.
Morman, S. A., and G. S. Plumlee, 2013: The role of airborne mineral dusts in human disease. Aeolian Res., 9, 203-212, https://doi.org/10.1016/j.aeolia. 2012.12.001.

Moulin, C., and I. Chiapello, 2004: Evidence of the control of summer atmospheric transport of African dust over the Atlantic by Sahel sources from TOMS satellites (1979-2000). Geophys. Res. Lett., 31, L02107, https://doi. org/10.1029/2003GL018931.

— C. E. Lambert, F. Dulac, and U. Dayan, 1997: Control of atmospheric export of dust from North Africa by the North Atlantic oscillation. Nature, 387, 691-694, https://doi.org/10.1038/42679.

Mulitza, S., and Coauthors, 2010: Increase in African dust flux at the onset of commercial agriculture in the Sahel region. Nature, 466, 226-228, https:// doi.org/10.1038/nature09213.

Ott, S. T., A. Ott, D.W. Martin, and J.A. Young, 1991:Analysis of a trans-Atlantic Saharan dust outbreak based on satellite and gate data. Mon. Wea. Rev., 119, 1832-1850, https://doi.org/10.1175/1520-0493(1991)119<1832:AOATAS>2.0.C0;2.

Perry, K. D., T. A. Cahill, R. A. Eldred, D. D. Dutcher, and T. E. Gill, 1997: Long-range transport of North African dust to the eastern United States. J. Geophys. Res., 102, 11 225-11 238, https://doi.org/10.1029/97JD00260.

Prospero, J. M., and T. N. Carlson, 1972: Vertical and areal distribution of Saharan dust over western equatorial North-Atlantic Ocean. J. Geophys. Res., 77, 5255-5265, https://doi.org/10.1029/JC077i027p05255.

_ Pure Appl. Geophys., 119, 677-691, https://doi.org/10.1007/BF00878167.

_ Climate change implications.Science, 302,1024-1027, https://doi.org/10.1126 Iscience.1089915.

_ African dust on the Caribbean basin. Bull. Amer. Meteor. Soc., 94, 1329-1337, https://doi.org/10.1175/BAMS-D-12-00142.1.

_ I. Olmez, and M. Ames, 2001: Al and Fe in PM 2.5 and PM 10 suspended particles in south-central Florida: The impact of the long range transport of African mineral dust. Water Air Soil Pollut., 125, 291-317, https://doi. org/10.1023/A:1005277214288.

_ - P. Ginoux, O. Torres, S. E. Nicholson, and T. E. Gill, 2002: Environmental characterization of global sources of atmospheric soil dust identified with the Nimbus 7 Total Ozone Mapping Spectrometer (TOMS) absorbing aerosol product. Rev. Geophys., 40, 1002, https://doi.org/10.1029/2000RG000095.

_ F. X. Collard, J. Molinie, and A. Jeannot, 2014: Characterizing the annual cycle of African dust transport to the Caribbean Basin and South America and its impact on the environment and air quality. Global Biogeochem. Cycles, 28, 757-773, https://doi.org/10.1002/2013GB004802.

$\mathrm{Pu}, \mathrm{B}$. , and P. Ginoux, 2017: Projection of American dustiness in the late 21st century due to climate change. Sci. Rep., 7, 5553, https://doi.org/10.1038/ s41598-017-05431-9.

_ cal depth? Atmos. Chem. Phys., 18, 12 491-12 510, https://doi.org/10.5194/ acp-18-12491-2018.

_, and _ $2018 \mathrm{~b}$ : Climatic factors contributing to long-term variations in surface fine dust concentration in the United States. Atmos. Chem. Phys., 18, 4201-4215, https://doi.org/10.5194/acp-18-4201-2018.

Raj, J., H. K. Bangalath, and G. Stenchikov, 2019: West African monsoon: Current state and future projections in a high-resolution AGCM. Climate Dyn., 52, 6441-6461, https://doi.org/10.1007/s00382-018-4522-7.

Ridley, D. A., C. L. Heald, and J. M. Prospero, 2014: What controls the recent changes in African mineral dust aerosol across the Atlantic? Atmos. Chem. Phys., 14, 5735-5747, https://doi.org/10.5194/acp-14-5735-2014.

Rodríguez, S., and Coauthors, 2015: Modulation of Saharan dust export by the North African dipole. Atmos. Chem. Phys., 15, 7471-7486, https://doi. org/10.5194/acp-15-7471-2015.

Sassen, K., 1991: The polarization lidar technique for cloud research: A review and current assessment. Bull. Amer. Meteor. Soc., 72, 1848-1866, https://doi. org/10.1175/1520-0477(1991)072<1848:TPLTFC>2.0.CO;2. 
Sayer, A. M., N. C. Hsu, J. Lee, W. V. Kim, and S. T. Dutcher, 2019: Validation, stability, and consistency of MODIS collection 6.1 and VIIRS version 1 deep blue aerosol data over land. J. Geophys. Res. Atmos., 124, 4658-4688, https://doi. org/10.1029/2018JD029598.

Schepanski, K., I. Tegen, and A. Macke, 2009: Saharan dust transport and deposition towards the tropical northern Atlantic. Atmos. Chem. Phys., 9, 11731189, https://doi.org/10.5194/acp-9-1173-2009.

_ B. Heinold, and I. Tegen, 2017: Harmattan, Saharan heat low, and West African monsoon circulation: Modulations on the Saharan dust outflow towards the North Atlantic. Atmos. Chem. Phys., 17, 10223-10243, https:// doi.org/10.5194/acp-17-10223-2017.

Schweitzer, M. D., and Coauthors, 2018: Lung health in era of climate change and dust storms. Environ. Res., 163, 36-42, https://doi.org/10.1016/j.envres .2018.02.001.

Skinner, C. B., and N. S. Diffenbaugh, 2014: Projected changes in African easterly wave intensity and track in response to greenhouse forcing. Proc. Natl. Acad. Sci. USA, 111, 6882-6887, https://doi.org/10.1073/pnas.1319597111.

Solmon, F., N. Elguindi, and M. Mallet, 2012: Radiative and climatic effects of dust over West Africa, as simulated by a regional climate model. Climate Res., $\mathbf{5 2}$, 97-113, https://doi.org/10.3354/cr01039.

Strong, J. D., G. A. Vecchi, and P. Ginoux, 2018: The climatological effect of Saharan dust on global tropical cyclones in a fully coupled GCM. J. Geophys. Res. Atmos., 123, 5538-5559, https://doi.org/10.1029/2017JD027808.

_ _ _ and P. Ginoux, 2015: The response of the tropical Atlantic and West African climate to Saharan dust in a fully coupled GCM. J. Climate, 28, 70717092, https://doi.org/10.1175/JCLI-D-14-00797.1.

Taylor, M. A., F. S. Whyte, T. S. Stephenson, and J. D. Campbell, 2013: Why dry? Investigating the future evolution of the Caribbean low level jet to explain projected Caribbean drying. Int. J. Climatol., 33, 784-792, https://doi. org/10.1002/joc.3461.

Thomas, N., and S. Nigam, 2018: Twentieth-century climate change over Africa: Seasonal hydroclimate trends and Sahara Desert expansion. J. Climate, 31, 3349-3370, https://doi.org/10.1175/JCLI-D-17-0187.1.
Thorncroft, C. D., and M. Blackburn, 1999: Maintenance of the African easterly jet. Quart. J. Roy. Meteor. Soc., 125, 763-786, https://doi.org/10.1002/ qj. 49712555502.

Veefkind, J. P., and Coauthors, 2012: TROPOMI on the ESA Sentinel-5 Precursor: A GMES mission for global observations of the atmospheric composition for climate, air quality and ozone layer applications. Remote Sens. Environ., 120, 70-83, https://doi.org/10.1016/..rse.2011.09.027.

Wang, C. Z., 2007: Variability of the Caribbean low-level jet and its relations to climate. Climate Dyn., 29, 411-422, https://doi.org/10.1007/s00382-007-0243-z.

_ , S. F. Dong, A. T. Evan, G. R. Foltz, and S. K. Lee, 2012: Multidecadal covariability of North Atlantic sea surface temperature, African dust, Sahel rainfall, and Atlantic hurricanes. J. Climate, 25, 5404-5415, https://doi.org/10.1175/ JCLI-D-11-00413.1.

Weinzierl, B., and Coauthors, 2017: The Saharan Aerosol Long-Range Transport and Aerosol-Cloud-Interaction Experiment: Overview and selected highlights. Bull. Amer. Meteor. Soc., 98, 1427-1451, https://doi.org/10.1175/BAMS-D-15-00142.1.

Winker, D. M., W. Hunt, and C. Hostetler, 2004: Status and performance of the CALIOP lidar. Proc. SPIE, 5575, 8-15, https://doi.org/10.1117/12.571955.

— - _ and M. J. McGill, 2007: Initial performance assessment of CALIOP. Geophys. Res. Lett., 34, L19803, https://doi.org/10.1029/2007GL030135.

Wu, C. L., Z. H. Lin, and X. H. Liu, 2020: The global dust cycle and uncertainty in CMIP5 (Coupled Model Intercomparison Project phase 5) models. Atmos. Chem. Phys., 20, 10401-10425, https://doi.org/10.5194/acp-20-10401-2020.

Yu, H. B., and Coauthors, 2015: The fertilizing role of African dust in the Amazon rainforest: A first multiyear assessment based on data from cloud-aerosol lidar and infrared pathfinder satellite observations. Geophys. Res. Lett., 42, 1984-1991, https://doi.org/10.1002/2015GL063040.

Yuan, T., H.Yu, M. Chin, L. A. Remer, D. McGee, and A. Evan, 2020:Anthropogenic decline of African dust: Insights from the Holocene records and beyond. Geophys. Res. Lett., 47, e2020GL089711, https://doi.org/10.1029/2020GL089711.

Zender, C. S., and E. Y. Kwon, 2005: Regional contrasts in dust emission responses to climate. J. Geophys. Res., 110, D13201, https://doi.org/10.1029 12004JD005501. 